\title{
Original
}

\section{Evaluation of Antimicrobial Effects on Dental Impression Materials and Biofilm Removal by Sodium Dichloroisocyanurate}

\author{
HIROKO HIRAMINE ${ }^{1 *}$, KIYOKO WATANABE ${ }^{2}$, KEITARO INABA ${ }^{2}$, \\ HARUKA SASAKI ${ }^{2}$, AND NOBUSHIRO HAMADA ${ }^{2}$ \\ ${ }^{1}$ Department of Highly Advanced Stomatology, Graduate School of Dentistry, Kanagawa Dental University, \\ 3-31-6, Tsuruya-cho, Kanagawa, Yokohama, 221-0835, Japan. \\ ${ }^{2}$ Department of Oral Science, Graduate School of Dentistry, Kanagawa Dental University, \\ 82 Inaoka-cho, Yokosuka, 238-8580, Japan.
}

Received 14 July, 2020/Accepted 16 September, 2020

\begin{abstract}
Dental materials are inevitably contaminated with oral microorganisms. To prevent transmission of infectious diseases, impressions need to be disinfected. In the present study, we examined the disinfection effects on impression materials and biofilm removal by sodium dichloroisocyanurate (SDIC). Exponentially growing Streptococcus mutans, Escherichia coli, Staphylococcus aureus and Candida albicans, and dental plaque bacteria were suspended in phosphate buffered saline (PBS) and exposed for 1,5 and $10 \mathrm{~min}$ to $1 \mathrm{~mL}$ of the $10 \mathrm{ppm}$, $100 \mathrm{ppm}, 1,000 \mathrm{ppm}$, and 10,000 ppm SDIC solutions. The bactericidal effect was evaluated by colony forming units of each microorganisms. Moreover, the effect of SDIC solution on S. mutans biofilm was examined. Bactericidal effects of SDIC solutions on oral bacteria on dental impression surfaces were assessed and the surface quality of dental casts after immersion in SDIC solution for $\mathbf{3 0} \mathrm{min}$ was observed under a scanning electron microscope. The number of all bacterial strains, including plaque bacteria, were significantly decreased by SDIC solution treatment in a dose-dependent manner. Significant S. mutans biofilm removing activity of SDIC was observed in 1,000 and $10,000 \mathrm{ppm}$ solution. The number of oral bacteria adhering to the surfaces of impressions markedly decreased following 10-min immersion in the 1,000 ppm SDIC solution. The $30-\mathrm{min}$ immersion of dental impression in the 1,000 ppm SDIC solution did not adversely affect the surface roughness of dental casts. The results indicate that SDIC Solution is useful to deactivate oral bacteria on dental impression.
\end{abstract}

Key words : disinfection / sodium dichloroisocyanurate (SDIC) / antibacterial effect / biofilm removal / oral bacteria.

\section{INTRODUCTION}

Sodium dichloroisocyanurate (SDIC) is reported to possess great efficacy in killing microorganisms present in water, environmental surface and medical equipment (Proto et al., 2016). SDIC consists of two reactive chlorine atoms and can damage cell membranes, nucleic acid and proteins resulting in oxidative degradation of microorganism (Lechevallier et al., 1981). SDIC was reported that it could instantly kill Escherichia coli (E.

*Corresponding author. Tel: +81-45-313-0007, Fax: +81-45313-0027, E-mail : hiramine(a)kdu.ac.jp coli), Staphylococcus aureus (S. aureus), and fungi (Proto et al., 2016). Coates (Coates, 1988) reported that SDIC solution containing $4,000 \mathrm{ppm}$ available chlorine exhibited a similar bactericidal effect to sodium hypochlorite $(\mathrm{NaClO})$ solution containing 17,000 ppm available chlorine and demonstrated that SDIC was less prone to be inactivated by serum than $\mathrm{NaClO}$. Another report was also found that SDIC was significantly superior to $\mathrm{NaClO}$ in comparing the antibacterial effects in the presence of organic materials (Bloomfield and Uso, 1985). Recently, SDIC has been approved by the United States Environmental Protection Agency (USEPA) and the World Health Organization (WHO) for the routine 
treatment of drinking water based on the findings of previous studies that investigated the toxicity and irritancy of this product (Clasen and Edmondson, 2006). These studies demonstrated that dry chlorinated isocyanurates were not corrosive and only slightly toxic, were not metabolized by organisms, did not bio-accumulate, and were safe to handle (Clasen and Edmondson, 2006).

In dentistry, dental materials are often contaminated with oral microorganisms. An impression is usually taken to make a dental cast for examination, diagnosis, and conservative and prosthetic treatments. Impression materials removed from patients are inevitably contaminated by contact with saliva, blood and bacterial plaque, which contains indigenous bacteria and potentially pathogenic microorganisms (Chidambaranathan and Balasubramanium, 2019; Egusa et al., 2008). Staphylococci, Streptococci, Pseudomonas, Escherichia coli, and Candida spp are known to be common contaminants in dental impressions (Badrian et al., 2012; Chidambaranathan and Balasubramanium, 2019). In order to reduce the risk of cross infection, dental materials need to be disinfected. Therefore, disinfection of dental impressions after removal from the patient's mouth is strongly recommended (Anonymous, 1996) and infection control has become an important issue for dental offices and dental laboratories in recent years.

Different disinfectants may be used including glutaraldehyde, $\mathrm{NaClO}$, iodophors, phenolic and alcohol compounds. Glutaraldehyde is preferred for disinfection, because it is bactericidal, virucidal, and fungicidal, but it can be highly toxic. $\mathrm{NaClO}$ is a water-soluble disinfectant used in surface and water disinfection. When dissolved in water, it forms hypochlorous acid, which in turn, dissociates into hydrochloric acid and oxygen atoms. Hypochlorous acid and oxygen atom are very strong oxidizers (Chidambaranathan and Balasubramanium, 2019). The antimicrobial action of $\mathrm{NaClO}$ is fast, effective, and broad spectrum, according to the American Dental Association (ADA) protocol (Pal et al., 2014).

The effects of a disinfectant are generally affected by the solution concentration, working time, and temperature. Jang et al., (Jang et al., 2017) demonstrated that 0.3\% SDIC solution possessed strong bactericidal efficacy against Salmonella enterica serovar Thyphimurium even for 1 min treatment at $-10^{\circ} \mathrm{C}$, whereas, $0.1 \%$ glutaraldehyde worked for 10 min treatment at $25^{\circ} \mathrm{C}$. Since many experimental researches have indicated its increased resistance to inactivation by organic material, slow decomposition and release of $\mathrm{HOCl}$, capacity to maintain an appropriate level of available chlorine, low level of toxicity and lower corrosiveness to metal, plastic and rubber (Block, 2001; Bloomfield and Miles, 1979; Coates, 1966; Kaye et al., 1991), the use of SDIC instead of $\mathrm{NaClO}$ has been recommended. However, there have been few reports to investigate the effectiveness of SDIC as a disinfectant to dental field (Heling et al., 2001; Patel et al., 2012).

The aims of the present study was to investigate the antimicrobial effects of SDIC on plaque bacteria, Streptococcus mutans (S. mutans), S. aureus, E. coli, and Candida albicans (C. albicans), and to assess the influence of SDIC disinfection on surface property of dental cast. This study will be beneficial to bring the new, safe, and low cost disinfection method of dental materials for daily use.

\section{MATERIALS AND METHODS}

\section{Subjects}

Seven male and eight female volunteers agreed to cooperate in the present study, were in good general health, and had a healthy oral cavity. The contents of the study were explained, and after obtaining consent, dental plaques were collected from subgingival surface of the lower first molar of subjects. An impression was taken with alginate impression material. The present study was conducted in accordance with the Kanagawa Dental University research ethics guidelines (approval number 592).

\section{Bacteria strains and growth conditions}

The following bacterial strains were used in the present study: S. mutans Ingbritt, S. aureus ATCC 12600, E. coli HB101, C. albicans ATCC10231, and dental plaque bacteria. S. mutans, S. aureus, E. coli and dental plaque bacteria were plated on brain heart infusion (BHI, Difco-BD, Sparls, MD, USA) agar medium supplemented with $5 \mathrm{mg}$ of yeast extract per $\mathrm{mL}$ and then incubated in an anaerobic chamber $\left(85 \% \mathrm{~N}_{2}\right.$, $10 \% \mathrm{H}_{2}$, and $5 \% \mathrm{CO}_{2}$ ) at $37^{\circ} \mathrm{C}$ for $5 \mathrm{~d}$. C. albicans was aerobically cultured in Nutrient agar plates (Nissui Pharmaceutical Co., Ltd., Tokyo, Japan) at $37^{\circ} \mathrm{C}$ for 1 d.

\section{Preparation of SDIC solution and effective chlorine concentrations}

Two disinfectants were used in the present study: SDIC and sodium hypochlorite $(\mathrm{NaClO})$. SDIC solution (Agusa TBS Tablets, AGUSA JAPAN, CO., LTD., Osaka, Japan) was examined as the test chlorine disinfectant and $\mathrm{NaClO}$ was used as a control. According to the method of use of the product, the available chlorine concentration of SDIC solutions was prepared by dissolving 1 tablet in $1 \mathrm{~L}$ of sterile distilled water, which concentration was $1,000 \mathrm{ppm}$. The $10,000 \mathrm{ppm}$ 
concentration SDIC solution was prepared by dissolving 1 tablet in $100 \mathrm{~mL}$ of sterile distilled water. The disinfectants were sterilized with a 0.45- $\mu \mathrm{m}$ filter (Millex Sterile syringe filter) and then prepared to 10, 100 ppm with sterilized water. The effective chlorine concentration of 1,000 ppm SDIC solution was measured over time using iodometric titration (Handy Water AQUAB Model AQ-202, CIO300f, SHIBATA SCIENTIFIC TECHNOLOGY, LTD., Saitama, Japan).

\section{Antibacterial effects on microorganisms}

The microbial strains used here were S. mutans, S. aureus, E. coli, and C. albicans, which have been commonly employed to evaluate antibacterial effects. Dental plaque was also used to examine disinfection effect. Microbial cultures and dental plaque samples were prepared to an optical density of 0.6 at $600 \mathrm{~nm}$ by PBS ( $\mathrm{pH}$ 7.2). Ten microliters of the bacterial suspension was exposed for 1,5 and $10 \mathrm{~min}$ to $1 \mathrm{~mL}$ of the $10,100,1,000$, and 10,000 ppm SDIC solutions or the same volume of PBS as a control. After exposure, 10-fold serial dilutions were obtained in PBS, and 100 $\mu \mathrm{L}$ of each dilution was spread onto a $\mathrm{BHI}$ agar plate or Nutrient agar plate and then incubated at $37^{\circ} \mathrm{C}$. Experiments on each bacterial strain and dental plaque bacteria were performed three times, and the number of viable bacteria was calculated from the number of colonies present on agar plates (colony forming units: CFU) to assess bactericidal effects. Bactericidal activity was defined as $>3 \log _{10} \mathrm{CFU} / \mathrm{mL}$ reduction.

\section{Removal of S. mutans biofilms by SDIC}

Removal ability of SDIC solution to preformed S. mutans biofilm was examined as follows. Overnight culture of $S$. mutans $(20 \mu \mathrm{L})$ was inoculated to tryptic soy broth $(100 \mu \mathrm{L})$ without dextrose supplemented with $0.1 \%$ sucrose in 96 well microtiter plates. After the plates were incubated at $37^{\circ} \mathrm{C}$ for $24 \mathrm{~h}$ under anaerobic conditions, the medium was removed and the wells were rinsed with PBS three times to remove planktonic cells. Then various concentrations of SDIC were added to the wells and incubated at $37^{\circ} \mathrm{C}$ for $30 \mathrm{~min}$. After the contact period, each well was washed three times with PBS and then stained with $0.25 \%$ safranin solution for 15 min and extracted with $70 \%$ ethanol for 30 min. The biofilms were quantified by measuring the absorbance of the extract at $492 \mathrm{~nm}$.

Furthermore, S. mutans biofilms were formed on round plastic coverslips (15 $\mathrm{mm}$ in diameter; Thermanox 174969, Nunc, Inc., Naperville, IL, USA) in tryptic soy broth with $0.1 \%$ sucrose for $24 \mathrm{~h}$ incubation. Then bacterial biofilms were exposed to $1,000 \mathrm{ppm}$ of the SDIC solution for 30 min or the same volume of PBS and distilled water as the control to examine the morphological change of $S$. mutans biofilm. The coverslips were washed with $0.1 \mathrm{M}$ sodium cacodylate buffer ( $\mathrm{pH} \mathrm{7.2)} \mathrm{and} \mathrm{fixed} \mathrm{with} \mathrm{1 \%} \mathrm{glutaraldehyde} \mathrm{in}$ $0.1 \mathrm{M}$ sodium cacodylate buffer for $1 \mathrm{~h}$. After rinsing, the biofilms were dehydrated through a graded series of aqueous ethanol solutions, and air dried. S. mutans biofilms were coated with a thin layer of platinum and observed using a scanning electron microscope (JCM-6000Plus, Japan Electron Optics Laboratory, Ltd., Tokyo, Japan).

\section{Detection of oral bacteria on the surface of alginate impression material}

A single jaw impression of the oral cavity of subjects was taken using alginate impression material (AROMA FINE DF III, MORMAL SET, GC, CO., Tokyo, Japan) with a metal tray (J. MORITA, CO., Osaka, Japan) according to the usual method. An impression of the right molar part of the lower jaw was taken from the same subject on different days to assess disinfection effects of SDIC. Impression material removed from the oral cavity was treated with 1) no treatment, 2) rinsed with sterilized water for $15 \mathrm{~s}$, and 3) rinsed with sterilized water for 15 $\mathrm{s}$ and then disinfected with the 1,000 ppm SDIC solution for 10 min. After each treatment, $\mathrm{BHI}$ agar medium was poured into the impression instead of gypsum and cultivated for $5 \mathrm{~d}$. In order to evaluate the bactericidal effects of SDIC solutions on oral bacteria on the dental impression surface, the surface of $\mathrm{BH}$ agar was irradiated with UV and assessed the presence of bacterial colonies. The reason for UV irradiation is to clarify the presence of bacterial colonies.

\section{Observation of gypsum cast surfaces using a scanning electron microscope}

A plaster model was made by taking an impression of a brass cylinder using a metal tray. The alginate impression material, kneaded by an automatic kneading machine (Rakuneru, GC, CO., Tokyo, Japan) was welded to brass cylinder, removed after $5 \mathrm{~min}$, and immersed in 1,000 ppm SDIC solution for $30 \mathrm{~min}$. Gypsum (New Plastone, GC, CO., Tokyo, Japan) was poured onto the surface of the impression and allowed to set at room temperature for $1 \mathrm{~h}$. The surfaces of gypsum casts were observed under a scanning electron microscope (JSM-6301F SEM, Japan Electron Optics Laboratory, Ltd., Tokyo, Japan) at a magnification of $x$ 2,000 .

\section{Statistical analysis}

Differences among experimental groups were analyzed by one-way analysis of variance and Tukey's test. $P$ values less than 0.05 were considered to be significant. 
TABLE 1. Antibacterial effects of the disinfectants against S. mutans

\begin{tabular}{|c|c|c|c|c|c|c|}
\hline \multirow[b]{2}{*}{ Disinfectant } & \multirow{2}{*}{$\begin{array}{l}\text { Time } \\
(\min )\end{array}$} & \multicolumn{5}{|c|}{ Concentration (ppm) } \\
\hline & & 0 & 10 & 100 & 1,000 & 10,000 \\
\hline \multirow[t]{3}{*}{ SDIC } & 1 & $2.86 \pm 0.47$ & $2.14 \pm 1.63$ & $0.31 \pm 0.08^{\star *}$ & $0^{\star \star}$ & $0^{\star \star}$ \\
\hline & 5 & $2.64 \pm 0.58$ & $2.19 \pm 0.07$ & $0^{* *}$ & $0^{* *}$ & $0^{* \star}$ \\
\hline & 10 & $2.81 \pm 1.41$ & $1.13 \pm 0.28$ & $0^{*}$ & $0^{*}$ & $0^{*}$ \\
\hline \multirow[t]{3}{*}{$\mathrm{NaClO}$} & 1 & $2.86 \pm 0.47$ & $1.79 \pm 0.77$ & $0.03 \pm 0.04^{\star \star}$ & $0^{\star \star}$ & $0^{* \star}$ \\
\hline & 5 & $2.64 \pm 0.58$ & $2.25 \pm 0.49$ & $0.00 \pm 0.00^{\star *}$ & $0^{\star \star}$ & $0^{* \star}$ \\
\hline & 10 & $2.81 \pm 1.41$ & $2.97 \pm 0.56$ & $0.00 \pm 0.00^{\star}$ & $0^{*}$ & $0^{*}$ \\
\hline
\end{tabular}

Data are shown as mean $\pm \mathrm{SD}$ of $1 \times 10^{7} \mathrm{CFU} / \mathrm{mL}$.

Asterisks indicate $p$ values for difference from control (without disinfectant): ${ }^{*} P<0.05,{ }^{* *} P<0.01$.

TABLE 2. Antibacterial effects of the disinfectants against $S$. aureus

\begin{tabular}{|c|c|c|c|c|c|c|}
\hline \multirow{2}{*}{ Disinfectant } & \multirow{2}{*}{$\begin{array}{l}\text { Time } \\
\text { (min) }\end{array}$} & \multicolumn{5}{|c|}{ Concentration (ppm) } \\
\hline & & 0 & 10 & 100 & 1,000 & 10,000 \\
\hline \multirow[t]{3}{*}{ SDIC } & 1 & $1.55 \pm 0.52$ & $1.56 \pm 0.13$ & $0.34 \pm 0.07^{\star \star}$ & $0^{\star \star}$ & $0^{* \star}$ \\
\hline & 5 & $1.75 \pm 0.36$ & $1.57 \pm 0.32$ & $0.01 \pm 0.01^{\star \star}$ & $0^{* \star}$ & $0^{\star \star}$ \\
\hline & 10 & $1.73 \pm 0.08$ & $0.96 \pm 0.22^{*}$ & $0^{\star \star}$ & $0^{* *}$ & $0^{* *}$ \\
\hline \multirow[t]{3}{*}{$\mathrm{NaClO}$} & 1 & $1.55 \pm 0.52$ & $1.44 \pm 0.05$ & $0.84 \pm 0.08$ & $0^{* *}$ & $0^{* \star}$ \\
\hline & 5 & $1.75 \pm 0.36$ & $1.55 \pm 0.24$ & $0.32 \pm 0.01^{\star \star}$ & $0^{* \star}$ & $0^{\star \star}$ \\
\hline & 10 & $1.73 \pm 0.08$ & $1.27 \pm 0.41$ & $0^{\star \star}$ & $0^{\star \star}$ & $0^{\star \star}$ \\
\hline
\end{tabular}

Data are shown as mean $\pm \mathrm{SD}$ of $1 \times 10^{7} \mathrm{CFU} / \mathrm{mL}$.

Asterisks indicate $p$ values for difference from control (without disinfectant): ${ }^{*} P<0.05,{ }^{*} P<0.01$.

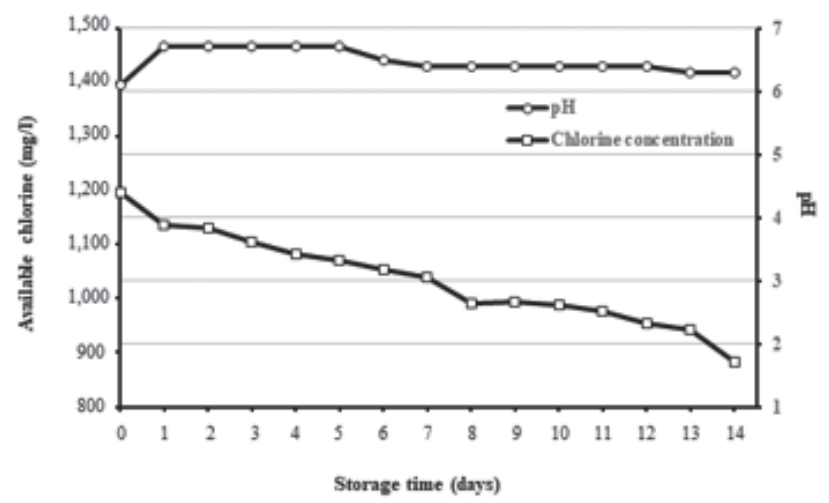

FIG. 1. Stability of the SDIC solution at room temperature. SDIC solution (1,000 ppm) was kept in glass bottle container with lid at $28^{\circ} \mathrm{C}$ (room temperature) for $2 \mathrm{wk}$. Periodically, the $\mathrm{SDIC}$ solution was taken, the available chlorine content and $\mathrm{pH}$ of the solutions were determined. The data are expressed as the mean \pm standard deviation in triplicate samples.

\section{RESULTS}

Comparison of effective SDIC solution concentrations One SDIC tablet was dissolved in 1,000 mL distilled water to prepare 1,000 ppm SDIC solution. In order to confirm the stability of SDIC solution, the SDIC solution was kept in containers (glass bottles with lids) at $28^{\circ} \mathrm{C}$ (room temperature) for 2 wk. The SDIC solution was periodically collected, and the available chlorine content and $\mathrm{pH}$ of the solution was assessed. The $\mathrm{pH}$ of the SDIC solution was stable even after 2 wk. However, the effective chlorine concentration decreased in a timedependent manner (Fig. 1).

\section{Antimicrobial effects on gram-positive, gram- negative bacteria and $C$. albicans.}

The antimicrobial effects of the SDIC and $\mathrm{NaClO}$ are shown in Tables 1 to 4 . Overnight culture of $S$. mutans, 
TABLE 3. Antibacterial effects of the disinfectants against $E$. coli

\begin{tabular}{|c|c|c|c|c|c|c|}
\hline \multirow{2}{*}{ Disinfectant } & \multirow{2}{*}{$\begin{array}{l}\text { Time } \\
(\min )\end{array}$} & \multicolumn{5}{|c|}{ Concentration (ppm) } \\
\hline & & 0 & 10 & 100 & 1,000 & 10,000 \\
\hline \multirow[t]{3}{*}{ SDIC } & 1 & $1.13 \pm 0.11$ & $1.24 \pm 0.25$ & $0.08 \pm 0.07^{\star \star}$ & $0^{* *}$ & $0^{\star \star}$ \\
\hline & 5 & $1.39 \pm 0.08$ & $0.99 \pm 0.15^{\star \star}$ & $0^{\star \star}$ & $0^{\star \star}$ & $0^{\star \star}$ \\
\hline & 10 & $1.03 \pm 0.21$ & $1.13 \pm 0.28$ & $0^{* \star}$ & $0^{* *}$ & $0^{* *}$ \\
\hline \multirow[t]{3}{*}{$\mathrm{NaClO}$} & 1 & $1.13 \pm 0.11$ & $1.20 \pm 0.05$ & $0.06 \pm 0.02^{\star \star}$ & $0^{* *}$ & $0^{* \star}$ \\
\hline & 5 & $1.39 \pm 0.08$ & $1.16 \pm 0.05$ & $0.04 \pm 0.01^{\star \star}$ & $0^{\star \star}$ & $0^{\star \star}$ \\
\hline & 10 & $1.03 \pm 0.21$ & $1.15 \pm 0.03$ & $0^{\star \star}$ & $0^{\star \star}$ & $0^{\star \star}$ \\
\hline
\end{tabular}

Data are shown as mean $\pm \mathrm{SD}$ of $1 \times 10^{7} \mathrm{CFU} / \mathrm{mL}$.

Asterisks indicate $p$ values for difference from control (without disinfectant): ${ }^{\star} P<0.05,{ }^{\star \star} P<0.01$.

TABLE 4. Antimicrobial effects of the disinfectants against C. albicans

\begin{tabular}{|c|c|c|c|c|c|c|}
\hline \multirow{2}{*}{ Disinfectant } & \multirow{2}{*}{$\begin{array}{l}\text { Time } \\
\text { (min) }\end{array}$} & \multicolumn{5}{|c|}{ Concentration (ppm) } \\
\hline & & 0 & 10 & 100 & 1,000 & 10,000 \\
\hline \multirow[t]{3}{*}{ SDIC } & 1 & $1.60 \pm 0.17$ & $1.57 \pm 0.06$ & $0.07 \pm 0.06^{\dagger \star \star}$ & $0^{\star \star}$ & $0^{\star \star}$ \\
\hline & 5 & $1.36 \pm 0.51$ & $0.95 \pm 0.08$ & $0^{* *}$ & $0^{* *}$ & $0^{\star *}$ \\
\hline & 10 & $1.40 \pm 0.10$ & $0.25 \pm 0.08^{\star *}$ & $0^{\star *}$ & $0^{\star *}$ & $0^{\star *}$ \\
\hline \multirow[t]{3}{*}{$\mathrm{NaClO}$} & 1 & $1.60 \pm 0.17$ & $1.50 \pm 0.12$ & $1.41 \pm 0.10$ & $0^{* \star}$ & $0^{\star *}$ \\
\hline & 5 & $1.36 \pm 0.51$ & $1.78 \pm 0.42$ & $0.04 \pm 0.03^{\star \star}$ & $0^{* *}$ & $0^{* \star}$ \\
\hline & 10 & $1.40 \pm 0.10$ & $1.23 \pm 0.30$ & $0^{\star \star}$ & $0^{\star *}$ & $0^{* *}$ \\
\hline
\end{tabular}

Data are shown as mean $\pm \mathrm{SD}$ of $1 \times 10^{6} \mathrm{CFU} / \mathrm{mL}$.

${ }^{\dagger}$ Statistically different from the other disinfectant in the same treatment period $(P<0.01)$.

Asterisks indicate $p$ values for difference from control (without disinfectant): ${ }^{\star} P<0.05,{ }^{\star \star} P<0.01$.

S. aureus, E. coli and C. albicans were exposed to 0, 10, 100, 1,000, and 10,000 ppm SDIC solution for 1 , 5, and 10 min and viable cell numbers were evaluated. Exposure to 1,000 ppm and 10,000 ppm SDIC solution for 1 min completely eliminated all microbial strains (Tables 1 to 4). Treatment with 100 ppm SDIC solution for more than 5 min also showed bactericidal activity against S. mutans, E. coli and C. albicans. Furthermore, the number of viable bacteria significantly decreased in all microorganisms in 100 ppm SDIC solution for 1 min treatment $(P<0.01)$. Treatment with $1,000 \mathrm{ppm}$ and 10,000 ppm NaClO had comparable efficacy to SDIC against all microbial strains. However, lower disinfection efficacy was observed in $100 \mathrm{ppm} \mathrm{NaClO}$, especially, S. mutans was still alive for 10 min treatment with the disinfectant (Table 1). Moreover, 100 ppm NaClO had no microbial activity against $C$. albicans for 1 min treatment, while SDIC exhibited significant activity (Table 4).

\section{Bactericidal effect of disinfectants against dental plaque bacteria}

Table 5 shows the bactericidal effects of SDIC and $\mathrm{NaClO}$ against dental plaque bacteria. Dental plaques were collected from three subjects, pooled, and suspended in PBS, and then $10 \mu \mathrm{L}$ of the suspension was exposed to various concentrations of disinfectants. Dental plaque bacteria were more susceptible to both disinfectants. Exposure of the plaque specimen to 100, 1,000, and 10,000 ppm of SDIC and $\mathrm{NaClO}$ for $1 \mathrm{~min}$ eliminated plaque bacteria. In 10 ppm SDIC, the viable bacterial number was reduced time-dependently and significantly even for 1 min exposure (Table 5 ). 
TABLE 5. Antibacterial effects of the disinfectants against dental plaque bacteria

\begin{tabular}{|c|c|c|c|c|c|c|}
\hline \multirow{2}{*}{ Disinfectant } & \multirow{2}{*}{$\begin{array}{l}\text { Time } \\
\text { (min) }\end{array}$} & \multicolumn{5}{|c|}{ Concentration (ppm) } \\
\hline & & 0 & 10 & 100 & 1,000 & 10,000 \\
\hline \multirow[t]{3}{*}{ SDIC } & 1 & $2.33 \pm 0.72$ & $0.06 \pm 0.05^{\star \star}$ & $0^{\star \star}$ & $0^{\star *}$ & $0^{\star \star}$ \\
\hline & 5 & $2.00 \pm 0.72$ & $0.03 \pm 0.03^{\star \star}$ & $0^{\star \star}$ & $0^{\star \star}$ & $0^{\star \star}$ \\
\hline & 10 & $1.72 \pm 1.07$ & $0.00 \pm 0.01^{*}$ & $0^{*}$ & $0^{*}$ & $0^{*}$ \\
\hline \multirow[t]{3}{*}{$\mathrm{NaClO}$} & 1 & $2.33 \pm 0.72$ & $0.03 \pm 0.02^{\star *}$ & $0^{* \star}$ & $0^{* *}$ & $0^{\star *}$ \\
\hline & 5 & $2.00 \pm 0.72$ & $0.01 \pm 0.01^{\star *}$ & $0^{\star \star}$ & $0^{\star \star}$ & $0^{\star \star}$ \\
\hline & 10 & $1.72 \pm 1.07$ & $0.02 \pm 0.02^{\star}$ & $0^{*}$ & $0^{*}$ & $0^{*}$ \\
\hline
\end{tabular}

Data are shown as mean $\pm \mathrm{SD}$ of $1 \times 10^{6} \mathrm{CFU} / \mathrm{mL}$.

Asterisks indicate $p$ values for difference from control (without disinfectant): ${ }^{\star} P<0.05,{ }^{\star \star} P<0.01$.

\section{Removal of S. mutans biofilms by SDIS}

Various concentrations of SDIC solution were applied on preformed S. mutans biofilm. Exposure to SDIC containing 10,000 ppm and 1,000 ppm available chlorine resulted in significant biofilm reduction of around 40\% $(P<0.01)$ and 16\% $(P<0.05)$, respectively (Figure $2 \mathrm{~B}$ ). Figure $2 \mathrm{~A}$ shows scanning electron micrographs of $S$. mutans biofilms. S. mutans adhered to coverslips and formed thick clumps (Figs. 2A a, b). However, after exposure to the 1,000 ppm SDIC solution for $30 \mathrm{~min}$, bacterial cells sparsely adhered to coverslips and the thickness of clumps was reduced (Fig. 2A c).

\section{Bactericidal effects on alginate impression surfaces}

The effects of disinfection on the surface of alginate impression material are shown in Figure 3. The number of bacteria adhering to the impression surface was markedly lower following a 10-min immersion in the 1,000 ppm SDIC solution than after no treatment or rinsing with sterilized water for $15 \mathrm{~s}$. Similar bactericidal effects were obtained for other specimens.

\section{SEM observations of gypsum cast surfaces obtained from impressions.}

Figure 4 shows SEM images of the surface of the gypsum casts and the surface of the untreated gypsum casts after disinfection with $\times 500$ and $\times 2,000$ magnifications. The disinfectant used was the 1,000 ppm SDIC solution for $30 \mathrm{~min}$. No significant differences were observed in the crystal structure of the gypsum surface.

\section{DISCUSSION}

The present study investigated the antimicrobial activity of SDIC. SDIC is usually employed as a disinfectant
A
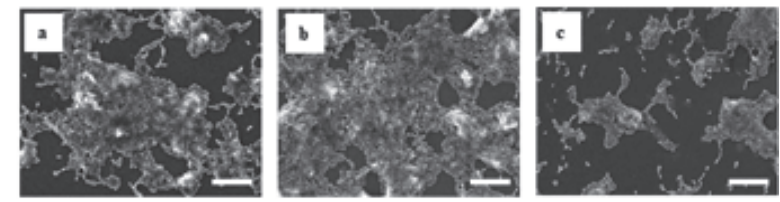

B

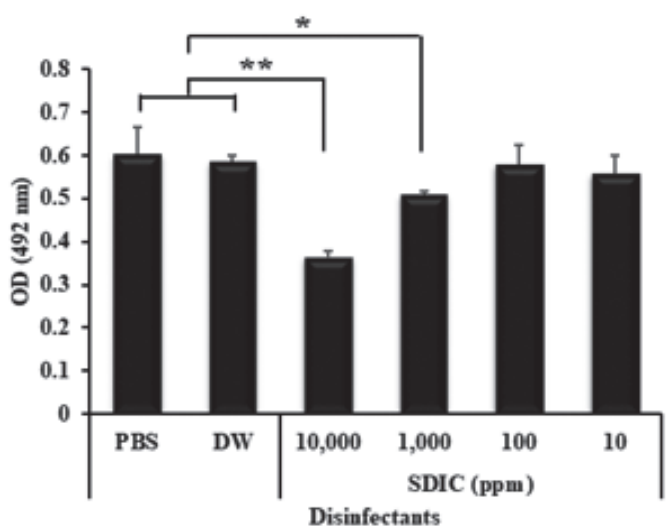

FIG. 2. A; SEM evaluation of S. mutans removed by SDIC solution.

Results of representative scanning electron micrographs of $S$. mutans. Immersion in 1,000 ppm of disinfectants for $10 \mathrm{~min}$. A: distilled water (a), PBS (b), SDIC (c). Scale bars. $20 \mu \mathrm{m}$. B: S. mutans pre-formed biofilm was treated with SDIC solution for $10 \mathrm{~min}$. The biofilm removal activity of SDIC was quantified by the saflanin staining method. ${ }^{\star} P<0.05$, ${ }^{\star \star} P<0.01$ (B).

for the treatment of water, environmental surfaces and medical equipment, however, is rarely used in dentistry. SDIC is rapidly hydrolyzed in water to become isocyanuric acid and hypochlorous acid, and hypochlorous acid has strong bactericidal effect. Among numerous reports demonstrated its effectiveness as a microbicide 

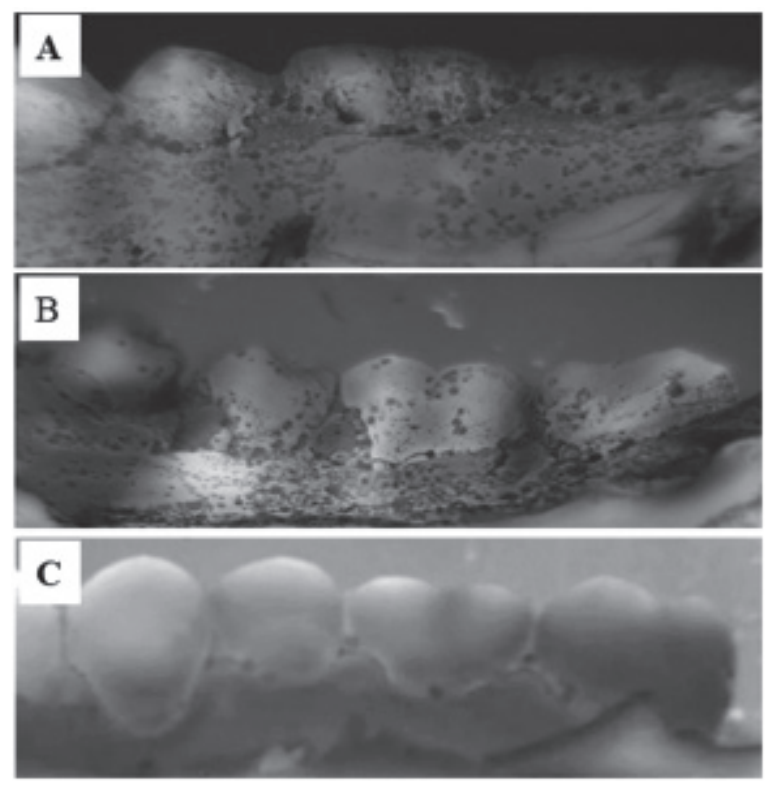

FIG. 3. Oral bacteria on the surface of the impression. Bacterial colonies were obviously decreased by 10 min-soak in 1,000 ppm of the SDIC solution compared with the non-treated surface or sterilized water wash.

A: Non-treated. B: Rinse with sterilized water for 15 s. C: Rinse with sterilized water for $15 \mathrm{~s}$, then disinfect with chlorine for 30 min.

agent, Bloomfield et al., (Bloomfield and Miles, 1979; Bloomfield and Uso, 1985) revealed that SDIC was more resistant to inactivation by organic material than $\mathrm{NaClO}$ and prolonged the release of $\mathrm{HClO}$ maintaining appropriate available chlorine level.

The residual chlorine concentration of SDIC solution at $28^{\circ} \mathrm{C}$ was shown to remain stable at $1,200 \mathrm{ppm}$ for $24 \mathrm{~h}$ (Fig. 1). Similarly, the $\mathrm{pH}$ of the SDIC solution was stable (Fig. 1). Chlorine loses its effectiveness to disinfect in a time-dependent manner. Hoffman (Hoffman et al., 1981) reported that one of the issues associated with $\mathrm{NaClO}$ solutions is instability, particularly at high temperatures. D'Auria et al. (D'Auria et al., 1989) reported that SDIC solutions were not adversely affected by temperature or $\mathrm{pH}$. As shown in Figure 1, the available chlorine concentration of SDIC solutions was still remain over 1,000 ppm for $7 \mathrm{~d}$. Hence, freshly prepared SDIC solution is required for use in dental practice. One SDIC tablet possesses 1,000 ppm of available chlorine in $1 \mathrm{~L}$ water, therefore, it is easy to prepare the appropriate concentration for use.

Both SDIC and $\mathrm{NaClO}$ solution in 1000 ppm showed bactericidal effects on S. mutans, S. aureus, E. coli, C. albicans, and plaque bacteria for 1 min treatment (Tables 1 to 5). However, 100 ppm SDIC solution possessed significantly higher efficacy against all species tested for 5 min treatment than $\mathrm{NaClO}$ had (Table 1).

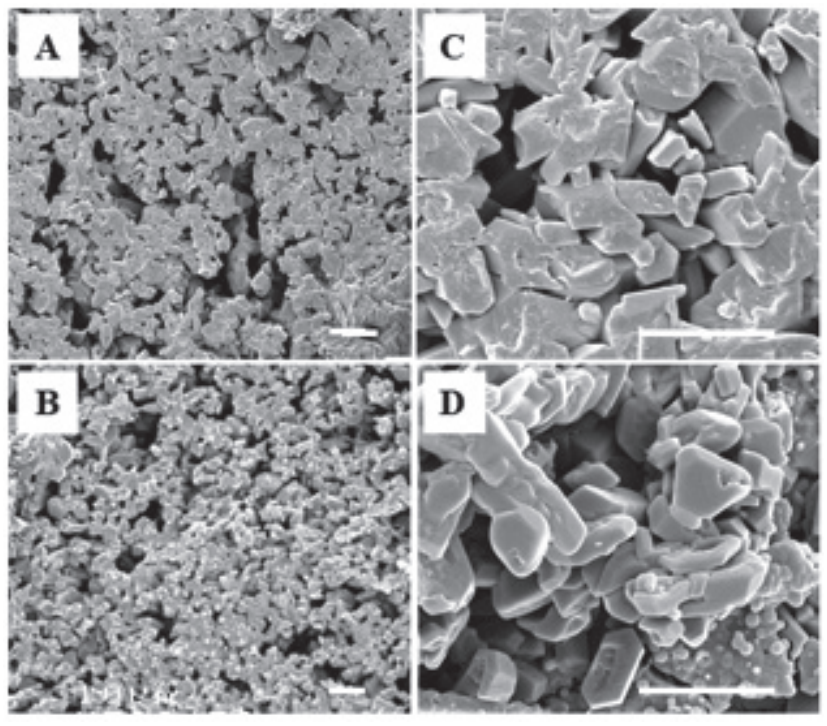

FIG. 4. Results of representative scanning electron micrographs of gypsum surface.

A and C: Immersion in 1,000 ppm of the SDIC solution for 30 min. B and D: No immersion in any disinfectants as a control. Scale bars, $10 \mathrm{~mm}$. (A and B: $\times 500 . \mathrm{C}$ and $\mathrm{D}: \times 2,000$ )

These microorganisms are common contaminants on the surface of dental impression from the patients. The Japanese Prosthodontic Association Editorial Guidelines recently recommend that alginate impressions were immersed in a $0.1-1.0 \% \mathrm{NaClO}$ solution for $15-30 \mathrm{~min}$ (Anonymous, 2007). The Centers for Disease Control and Prevention also recommended household bleach (1:10 dilution) for the disinfection of hydrocolloid impressions (Rutala and Weber, 2008). Superiority of SDIC solution may indicates that SDIC solution is more useful as a disinfectant. In this experiment, we tested S. mutans. S. mutans is a high proportion of bacteria resident in the oral cavity and is considered to be cariogenic bacteria. We would like to investigate the periodontopathic bacteria of anaerobic bacteria such as Porphyromonas gingivalis in the future.

We also examined the biofilm-removing ability of SDIC for $S$. mutans, which is common inhabitant of oral microflora. Oral biofilm is composed of multi-species of microorganism and $S$. mutans primary thrives in sticky biofilms on tooth surfaces. Exposure of S. mutans preformed biofilm to SDIC solution showed significant biofilm reduction (Fig. 2). The mechanism of SDIC to remove $S$. mutans biofilm is not clear, however, higher concentrations of SDIC, both 10,000 ppm and 1,000 ppm, bactericidally worked on planktonic $S$. mutans cells. Therefore, bactericidal action of SDIC may result 
in removing S. mutans biofilm. Oral biofilm is associated with dental caries, gingivitis and periodontitis, therefore, ability to remove biofilms is beneficial as a disinfectant in dental field.

Alginate impression material is the most commonly and frequently used impression material in prosthetic dentistry. Recently Demajo (Demajo, 2016) demonstrated about dental impression materials that alginate impression exhibited a higher microbial count than silicone impression material. Alginate impressions do not possess any antimicrobial properties, therefore, they must be disinfected following exposure to plaque bacteria, saliva and/or blood. In the present study, bacterial colonies forming on impression surfaces after being immersed for 10 min in the 1,000 ppm SDIC solution were markedly lower than that on surfaces in non-treated and in rinsed for $15 \mathrm{~s}$ with sterilized water (Fig. 3).

In order to obtain optimally made dental casts, the relationship between static and mobile structures must be accurately reproduced. In the present study, electron microscopic images of gypsum surfaces after the immersion of alginate impression material in SDIC for 30 min showed no significant differences from those that were not immersed. Iwasaki (Iwasaki et al., 2016) reported that the immersion of agar-alginate combined impressions in ortho phthalaldehyde solution even for 1 min degraded the surface properties of the resulting stone casts, whereas an immersion in $0.5 \% \mathrm{NaClO}$ solution did not have any serious adverse effects. Therefore, a 30-min immersion in the 1,000 ppm SDIC solution is considered to be a suitable disinfection method for the surface structures of dental casts. Further studies may be needed to investigate the effects of immersion period in the $1,000 \mathrm{ppm}$ SDIC solution on the dimensional accuracy of the resulting dental cast. However, SDIC offers many advantages in terms of superior bactericidal activity, stability, safety, costs and convenience. These results show that a medium-level disinfectant SDIC may be the material of choice for disinfecting impression material.

\section{Conclusion}

The experimental results indicate that $1,000 \mathrm{ppm}$ SDIC solution for 10-30 min could effectively deactivate oral bacteria contacted on alginate impression and thus could be a promising disinfectant technique in various dental clinical applications for impression materials.

\section{Disclosure statement}

None of the authors had any financial links with the company products used in this study. The authors declare no conflicts of interest.

\section{REFERENCES}

Anonymous. (1996) Infection control recommendations for the dental office and the dental laboratory. ADA Council on Scientific Affairs and ADA Council on Dental Practice. J Am Dent Assoc., 127 (5), 672-680.

Anonymous. (2007) The Japan Prosthodontic Society. A guideline for infection control protocol in prosthodontic practice. Ann Jpn Prosthodont Soc., 51, 629-689.

Badrian, H., Chasemi, E., Khalighinejad, N., and Hosseini, N. (2012) The effect of three different disinfection materials on alginate impression by spray method. ISRN Dent., 685151.

Block, S. S. (2001) Disinfection, sterilization, and preservation. Lippincott Williams \& Wilkins, Philadelphia 2001.

Bloomfield, S. F., and Miles, G. A. (1979) The antibacterial properties of sodium dichloroisocyanurate and sodium hypochlorite formulations. J Appl Bacteriol., 46, 65-73.

Bloomfield, S. F., and Uso, E. E. (1985) The antibacterial properties of sodium hypochlorite and sodium dichloroisocyanurate as hospital disinfectants. J Hosp Infect., 6 , 20-30.

Chidambaranathan, A. S., and Balasubramanium, M. (2019) Comprehensive review and comparison of the disinfection techniques currently available in the literature. $J$ Prosthodont., 28, e849-e856.

Clasen, T., and Edmondson, P. (2006) Sodium dichloroisocyanurate (NaDCC) tablets as an alternative to sodium hypochlorite for the routine treatment of drinking water at the household level. Int J Hyg Environ Health., 209, 173-181.

Coates, D. (1966) Sporicidal activity of sodium dichloroisocyanurate, peroxygen and glutarardehyde disinfectants against Bacillus subtilis. J Hosp Infect., 32 (4), 283-294.

Coates, D. (1988) Comparison of sodium hypochlorite and sodium dichloroisocyanurate disinfectants: neutralization by serum. J Hosp Infect., 11, 60-67.

D'Auria, F. D., Simonetti, G., and Strippoli, V. (1989) Antimicrobial activity exerted by sodium dichloroisocyanurate. Ann Ig., 1, 1445-1458.

Demajo, J. K. (2016) Effectiveness of Disinfectants on Antimicrobial and Physical Properties of Dental Impression Materials. Int J Prosthodont., 29 (1), 63-7.

Egusa, H., Watamoto, T., Abe, K., Kobayashi, M., Kaneda, Y., Ashida, S., Matsumoto, T., and Yatani, H. (2008) An analysis of the persistent presence of opportunistic pathogens on patient-derived dental impressions and gypsum casts. Int $J$ Prosthodont., 21, 62-68.

Heling, I., Rotstein, I., Dinur, T., Szwec-Levine, Y., and Steinberg, D. (2001) Bactericidal and Cytotoxic Effects of Soduym Hypochlorite and Sodium Dichloroisocyanurate Solutions In Vitro. J Endod., 27 (4), 278-280.

Hoffmann, P. N., Death, J. E., and Coates, D. (1981) The stability of sodium hypochlorite lutions. Disinfectants: Their Use and Evaluation of Effectiveness. 77-83.

Iwasaki, Y., Hiraguchi, H., Iwasaki, E., and Yoneyama, T. (2016) Effects of immersion disinfection of agar-alginate combined impressions on the surface properties of stone casts. Dent Mater J., 35, 45-50.

Jang, Y., Lee, K., Lee, M., Song, J., Chang, B., and Choe, N. (2017) Efficacy evaluation of commercial disinfectants by using Salmonella enterica serovar Typhimurium as a test organism. J. Vet. Science., 18 (2), 209-216.

Kaye, S., Graham, R., McCarthy, K., Green, J., Damjanovic, V., and Austin, M. (1991) Reducing disinfection wastage. Eye., 5 (1), 120-123.

Lechevallier, M. W., Evans, T. M., and Seidler, R. J. (1981) 
Effect of turbidity on chlorination efficiency and bacterial persistence in drinking water. Appl Envion Microbiol., 42, 159-167.

Pal, P. K., Kamble, S. S., Chaurasia, R. R., Chaurasia, V. R., Tiwari, S., and Bansal, D. (2014) Evaluation of different disinfactants on dimensional accuracy and surface quality of type IV gypsum casts retrieved from elastomeric impression materials. J Int Oral Health., 6, 77-81.

Patel, M., Ebonwu, J., and Cutler, E. (2012) Comparison of chlorine dioxide and dichloroisocyanurate disinfectants for use in the dental setting. SADJ., 167 (7), 364-368.

Proto, A., Zarrella, I., Cucciniello, R., Pironti, C., De, Caro. F., and Motta, O. (2016) Bactericidal and fungicidal activity in gas phase of sodium dichloroisocyanurate (NaDCC). Curr Microbiol., 73, 287-291.

Rutala, W. A., and Weber, D. J. (2008) Healthcare Infection Control Practices Advisory Committee. (HICPAC). Guideline for disinfection and sterilization in healthcare facilities, 2008. Atlanta: Centers for Disease Control and Prevention (CDC). 20-21, 39-42, 48-49, 88-89, 104-105. 